\title{
Mohs の新鮮組織法
}

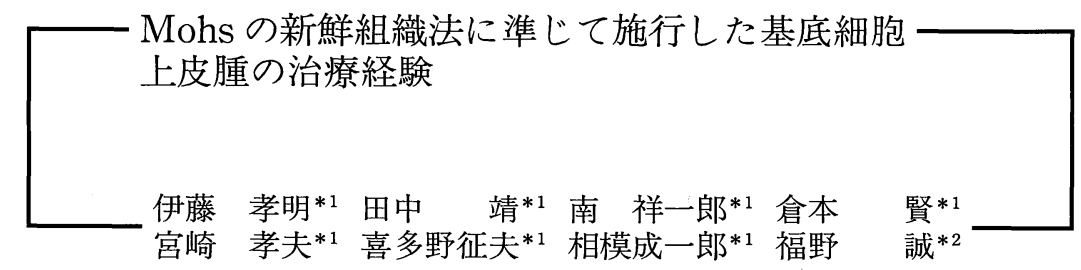

Summary

64歳, 女性の鼻背部基底細胞上皮腫に対し, Mohs の新鮮組織法 (Mohs micrographic surgery fresh-tissue technique）に準じた方法で摘出し, 正中前額皮弁により再建した症 例を経験した。Mohs の新鮮組織法は, 視診・触診にて, 術前に腫瘍の切除範囲が決定しに くいような基底細胞上皮腫には，良い適応と思われた。

はじめに

腫瘍の取り残しをなくし, 正常組織を最大限 に温存できる摘出手技の一つに，モス法(Mohs micrographic surgery）がある。

これは, 顕微鏡下に腫瘍細胞の有無を確認し つつ, 腫瘍細胞が完全になくなるまで，切除と 検鏡による確認を繰返す方法である。

この Mohs 法には，塩化亜鉛軟膏の外用によ ク, 腫瘍部を固定した後に行う固定組織法 (fixed-tissue technique ; chemosurgery) と, 固定を行わず，局麻下に腫瘍切除して同様の操 作を繰返す新鮮組織法 (fresh-tissue technique）とがある1) 。

今回, 私たちは, 腫瘍の辺縁が不明瞭な基底 細胞上皮腫に対し, Mohs の新鮮組織法に準じ

${ }^{* 1}$ Takaaki ITO, Yasushi TANAKA, Shoichiro MINAMI, Masaru KURAMOTO, Takao MIYAZAKI, Yukio KITANO, Seichiro SAGAMI : 兵庫医科大学皮膚科学教室

${ }^{* 2}$ Makoto FUKUNO : 東大阪市立中央病院皮膚科
た方法で切除し, 正中前額皮弁で再建した症例 を経験したので報告する。

\section{症例}

患 者：64歳, 女性

主 訴: 鼻背部の皮疹

現病歴: 平成元年11月頃, 鼻背左側の自覚症 状のない皮疹に気づいたが, 放置していた。平 成 2 年 2 月皮疹の拡大が気になり, 東大阪市立 中央病院皮膚科を受診した。

基底細胞上皮腫の診断にて同院にて，皮疹よ $\eta 4 \mathrm{~mm}$ 離して摘出され, 組織所見で切除辺縁 で，腫瘍細胞がみられたため，平成 2 年 3 月 23 日当科に紹介された。

既往歴・家族歴：特になし。

現 症: 鼻翼左側 (左内眼角内下方) に, 前 回の手術痕がある。その内下側に径約 $6 \mathrm{~mm}$ の 境界不明瞭な黒褐色斑と, 内側に $5 \times 3 \mathrm{~mm}$ の 不整形淡黒褐色斑が存在し，これらの周囲には 境界不明な浸潤を触れる（図 1 ）。

病理組織学的所見 : 東大阪市立中央病院での 摘出組織では, 腫瘍は好塩基性胞巣の形成, 辺 


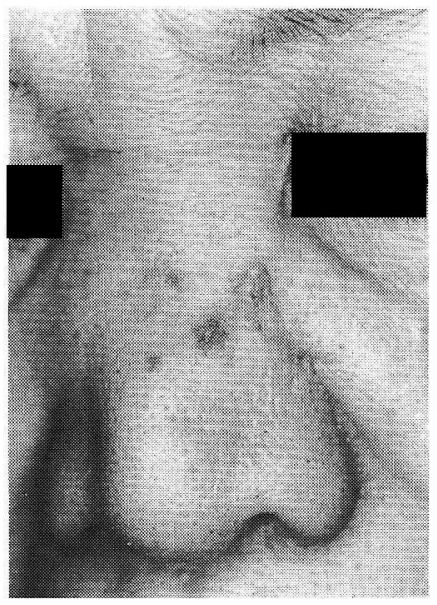

図 1. 入院時現症

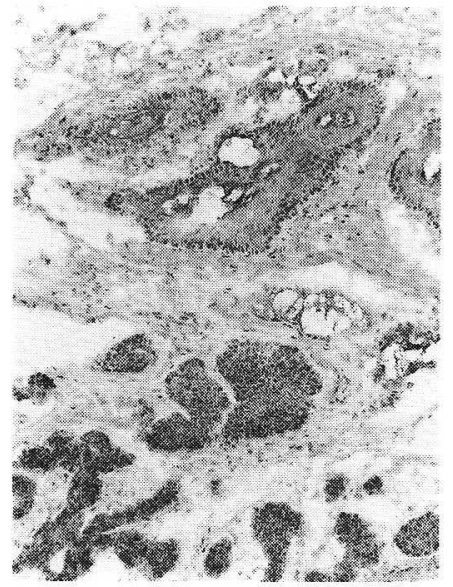

図 3.Mohs 法による凍結切片 H.E. 染色像

縁での柵状配列がみられ，基底細胞上皮腫と診 断したが, 組織辺縁でも腫瘍細胞が存在した(図 2 )。

治療と経過：平成 2 年 4 月 10 日，局麻下に皮 疹の辺縁から $3 \mathrm{~mm}$ 離して切除した。その組織 は, Mohs 法に準じて 4 分割して, 切除底面に平 行な凍結切片を作製, H.E. 染色し検鏡した。4 つの組織ブロックのうち 3 つのブロックで腫瘍 細胞が認められた(図 3 )。切除による皮䖉欠損 は，バイオブレーンで覆った。

この 2 日後，全麻下に手術を施行した。腫瘍 細胞の認められた 3 つのブロックの切除辺縁よ

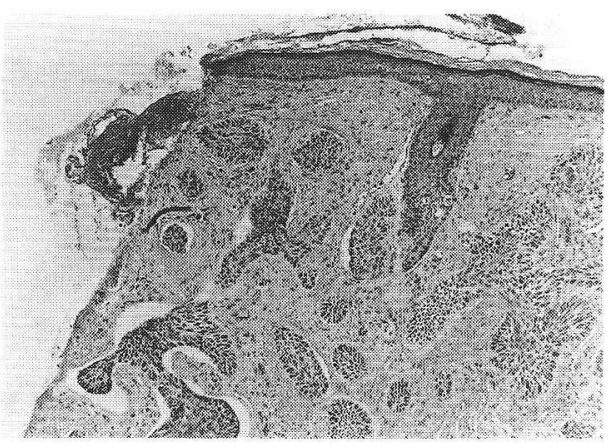

図 2.初回の摘出組織の辺縁

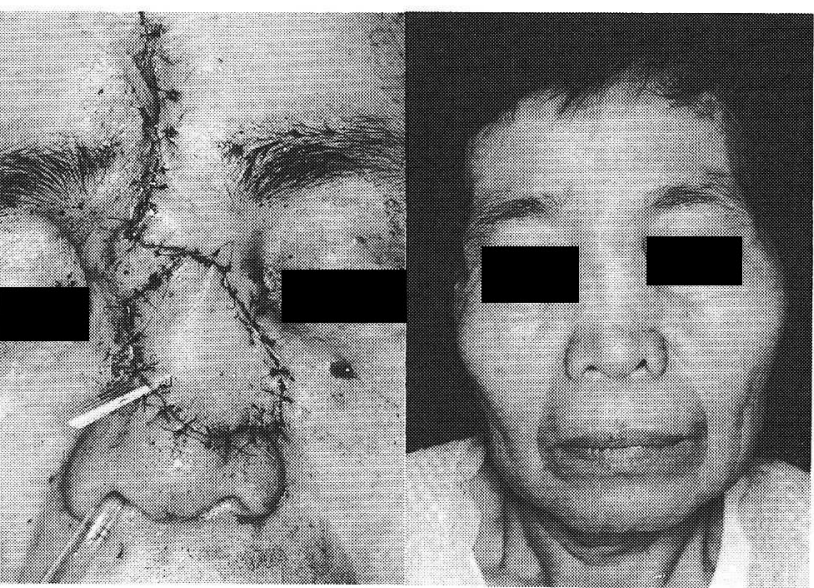

図 4. 正中前額皮弁による再建直後と術後 1 年

$\eta 3 \mathrm{~mm}$ 離して切除し， 3 分割して，同様に組 織標本を作製・検鏡したが，腫瘍細胞はみられ なかった。これにより腫瘍が完全に切除されて いると判断し，引続き正中前額皮弁を作成し， 皮虐欠損部を再建した。現在術後約 1 年経過し たが局所再発はなく,整容的にも問題はない(図 4 )。

\section{Mohs 法について}

図 5 は通常の組織切片作製法, 図 6 は Mohs の組織切片作製法の模式図である。 
(1)

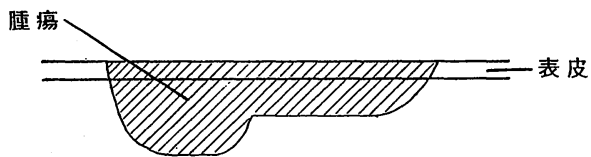

(2)

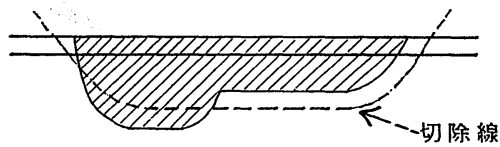

(3)
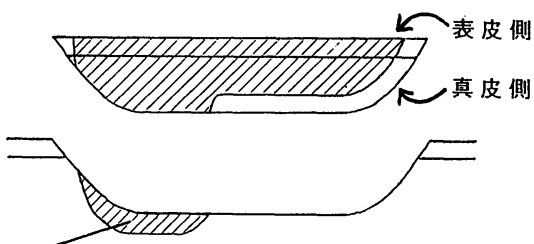

腫瘍が残つてしまう

(4)

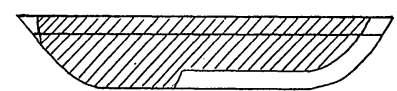

(5)

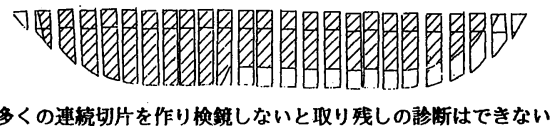

図 5. 通常の組織切片作製

図 5 (1)の皮膚腫瘍（一部で腫瘍細胞は深部に 及んでいる）に対し，正常組織を最大限に温存 するために, 図 5 (2)のように一定の幅・深さで 切除すると, 図 5 (3)下の如く腫瘍を取り残して しまう。しかも，図 5 (4)の切除組織を皮膚面に 対して垂直方向の切片（通常の切片）を作製す ると，取り残しの有無を組織診断するには，図 5 (5)のようにおびただしい数の組織検鏡が必要 となる。

これに対し Mohs 法では, 図 6 (1)の切除した 組織を，図6(2)のように分割して（この図では 2 分割), その組織は図 6 (3)の如く切除底面が平 になるように表皮側から圧迫した状態で凍結 し, 図 6 (4)のように切除組織の底面に平行な切 片を作製すると，図 6 (5)に示すように，少ない 検鏡で腫瘍細胞の有無を診断できる。

あるブロックで腫瘍細胞が認められれば，そ の周囲・底面をさらに切除し, 同様に凍結切片
(1)

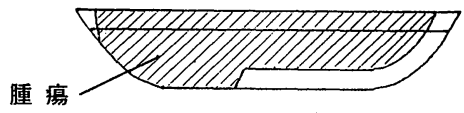

(2)

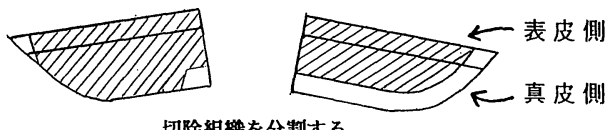

切除組轼を分割する

(3)
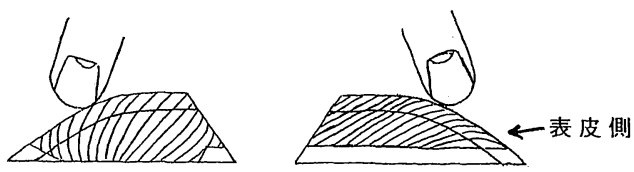

切除底面が平になる様に压迫しつつ凍結する (真皮 㒋

(4)
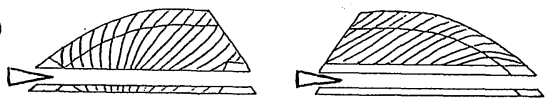

切除組峨の底面に平行な切片を作製する
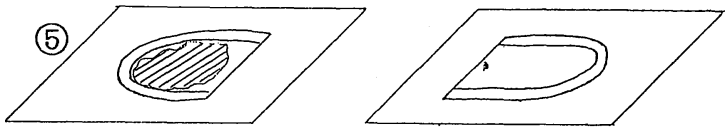

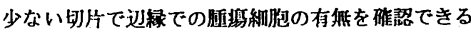

図 6.Mohs 法の組織切片作製

を作製し検鏡を行う。

なお，組織の分割・マッピングを行うのは， 再切除する部位を分かり易くするためである。

この Mohs 法の利点は,

1）腫瘍切除を顕微鏡下に確認できる。

2 ）正常組織を最大限に温存できる。

3 ) 術中に確定診断可能な場合もある。 欠点は,

1) 手術終了までに時間がかかる。

2 ）凍結切片の作製・観察に熟練を要する。

3 ）腫瘍細胞がある程度連続性をもって病巣 を構成する場合にしか信頼性がない。

病巣部を塩化亜鉛軟膏の外用により固定した 後, 前述の方法で凍結切片を作製するのが固定 組織法 (Mohs micrographic surgery fixedtissue technique; chemosurgery) であり, 固 定せず局麻下に行うのが新鮮組織法（freshtechnique）である。 


\section{考察}

初回の手術で, (1)皮疹の辺縁から $4 \mathrm{~mm}$ 離し て摘出されているにもかかわらず，組織切片の 辺縁で腫瘍細胞がみられたこと, (2)その手術痕 の近くにも，黒褐色斑が存在し，これも同腫瘍 が疑われること，(3)それらの皮疹および周囲の 浸潤の境界が不明瞭であること,より切除範囲 の決定が難しいと考え, Mohs 法に準じた方法 での治療計画を立てた。

しかし実際には, 組織の切除から, 標本を作 製し腫瘍細胞の有無を評価するまで 1 回あたり 約40分かかり, 組織所見で腫瘍細胞が見い出さ れないようになるまで繰返すには時間が必要と なる。全麻下ですべて行うと, 組織の結果の待 ち時間のために麻酔時間が長くなり，また局麻 下に行うには，患者には，かなりつらい手術で ある。

そこで今回は， 2 度に分けて行うこととし，
全麻下の摘出・再建術予定日の 2 日前に Mohs 法で切除・検鏡し, さらに切除すべき部位をマー クしておき, 再建術前にもう一度切除し, 腫瘍 がないことを顕微鏡下に確かめた上で, 再建す るという方法で行った。

結果的には患者の負担も少なく, 腫瘍は完全 摘出でき, 整容的な再建も行えたため, 良い方 法であったと考えている。

\section{文献}

1) 大塚壽: 新外科学体系. $29 \mathrm{~B}$, 出月康夫, 他編, 中 山書店, 東京, 1987. 110-116.

2 ) 清島真理子, 米田和史, 森俊二, 他: Mohs' Chemosurgery で治療した Spindle Cell Squamous Carcinoma. 西日皮䖉, $47: 429-433,1985$.

3 ) Perry Robins: Plastic Surgery. vol. 5, I. McCarthy, SAUNDERS, Philadelphia, 1990. 36523658.

4) Frederic, E. Mohs: Mohs Micrographic Surgery. George R. Mikhail, SAUNDERS, Philadelphia, 1991. 1-60. 